\title{
Monitoring and predicting the shoreline change in Can Gio area in condition of the sea level rise
}

- Bui Trong Vinh

- Huynh Trung Tin

- Le Nguyen Doan Trinh

- Ly Minh Hoang

- Le Thanh Phong

- Tran Le The Dien

University of Technology, VNU-HCM- btvinh@hcmut.edu.vn

(Manuscript Received on August 08 ${ }^{\text {th }}, 2014$; Manuscript Revised November 11 $1^{\text {th }}, 2014$ )

\section{ABSTRACT:}

Locating on the domestic and international navigation routes (Long Tau-Tac Dinh Cau route, Soai Rap route) the Can Gio area is impacted by waterway traffic activities. The seasonal movement of sand bars on the Can Gio is significantly impacted by hydrodynamic of the river mouth. With the important roles of the area, the authors consider the coastal morphology processes under the hydrodynamic. In this paper, the authors has inherited previous studies combined the satellite image analysis to detect the shoreline changes from 1973 to 2013. Besides, numerical modeling was also applied to predict the shoreline changes under impacts of the sea level rise. Results show that, the Can Gio shoreline prolonging from Can Thanh to Dong Hoa is seriously eroded, with average of 7-10 m/year, maximum to $15 \mathrm{~m} /$ year. It is found that, beach erosion at Can Gio is a kind of surface erosion impacted by human trigger (shrimp ponds, beach encroachment...). In addition, natural factors (wave, long-shore current, littoral materials) also contribute to increase the erosion rate. Predicted results with sea level rise scenarios show that, the Dong Hoa and Can Thanh will be seriously eroded while the 30-4 beach will be annually deposited.

Keywords: Can Gio, beach erosion, numerical modeling, GIS, sea level rise, shoreline change.

\section{INTRODUCTION}

Locating on the Southwest, Can Gio called "green lung" of the Ho Chi Minh City. The mangrove forest system is deemed the "priceless treasure" of the downstream of Sai Gon - Dong Nai river system. Several years ago, along with the development of socioeconomic and the impact of global climate change, the coastal erosion occurred seriously, which lead to narrow the mangrove forest, negatively impact on beach tourist and the local aquaculture. To assess the erosion mechanism, many researches have been carried out by applying of various methods: satellite image analysis, numerical modeling... In this paper, the authors have assessed the shoreline change at Can Gio beach (around $13 \mathrm{~km}$ from the Dong Hoa to Can Thanh cape). Figure 1 illustrates the study area. 


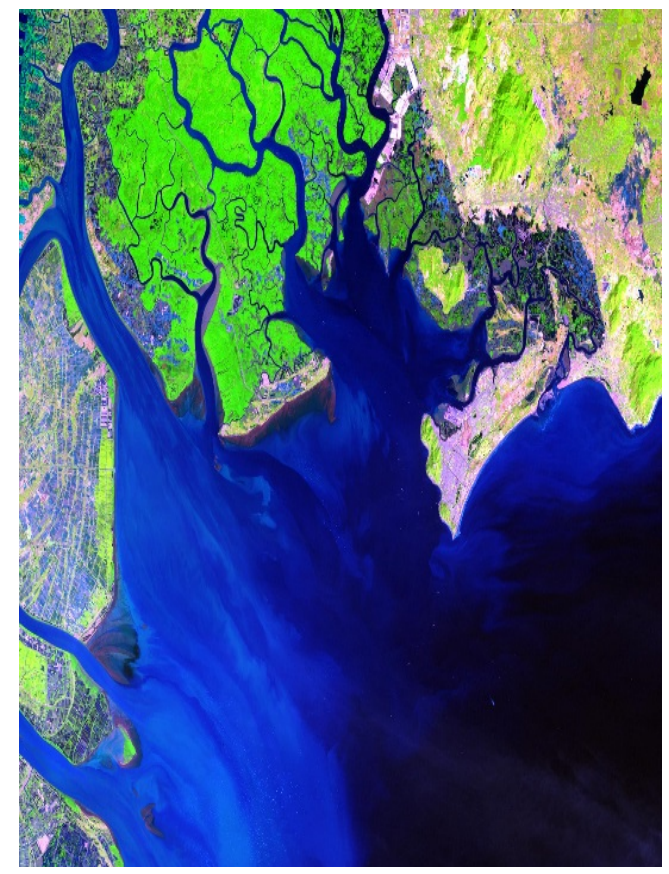

\section{STUDY METHOD}

\section{Geographic Information System (GIS)}

To assess the shoreline change, the satellite data from USGS (Landsat image) have been used. Parameter of satellite used are given in Table 1 below:

Table 1. Satellite data and calculated tidal level used for the study

\begin{tabular}{|l|c|c|c|}
\hline Satellite & Sensor & $\begin{array}{c}\text { Acquisition } \\
\text { date }\end{array}$ & Resolution \\
\hline Landsat 1-3 & SMSS & $01 / 01 / 1973$ & $60 \mathrm{~m}$ \\
\hline Landsat 4-5 & TM & $06 / 03 / 1989$ & $30 \mathrm{~m}$ \\
\hline Landsat 4-5 & TM & $11 / 02 / 1995$ & $30 \mathrm{~m}$ \\
\hline Landsat 4-5 & TM & $20 / 12 / 2004$ & $30 \mathrm{~m}$ \\
\hline Landsat 4-5 & TM & $18 / 12 / 2009$ & $30 \mathrm{~m}$ \\
\hline Landsat 8 & OLI & $01 / 04 / 2013$ & $30 \mathrm{~m}$ \\
\hline
\end{tabular}

The authors have combined the Band 5 (1.55-1.75 $\mu \mathrm{m}), 4(0.76-0.9 \mu \mathrm{m})$ and $3(0.69-0.63 \mu \mathrm{m})$, to determine the changes of land-cover through many years. After that, authors determined the location of shoreline by using images of Band $5(1.55-1.75 \mu \mathrm{m})$ and Band $2(0.76-0.90 \mu \mathrm{m})$ of Landsat/TM and evaluated the parameter $\mathrm{TM}_{5-2}$ defined as the following equation (Deguchi et al., 2005):

$$
T M_{5-2}=\frac{B 5-B 2}{B 5+B 2}
$$

By using the $\mathrm{TM}_{5-2}$ images, the radiance values in the pixel between land and sea are changed suddenly so that the shoreline change can be extracted easily. Besides, the land-cover analyzing may assess the change of land cover through many years.

\section{Numerical modelling}

To assess the potential impact of the sea level rise on the shoreline change, a model of "littoral processes and coastline kinetics" (LITPACK) was established. The main modules of the LITPACK are as the followings: Non-cohesive sediment transport (LIST); Long-shore current and littoral drift (LITDRIFT); Coastline evolution (LITLINE); Cross-shore profile evolution (LITPROF) and Sedimentation in trenches (LITTREN).

The LITLINE is developed based on the equation of the continuity for sediment volumes $\mathrm{Q}(\mathrm{x})$

$$
\frac{\partial y_{c}(x)}{\partial t}=-\frac{1}{h_{a c t}(x)} \frac{\partial Q(x)}{\partial x}+\frac{Q_{s o u}(x)}{h_{a c t}(x) \Delta x}
$$

Where: $y_{c}(x)$ is the coastline position; $t$ is time; $Q(x)$ is the volume of long-shore sediment transport; $x$ is the position; $h(x)$ - height of the active cross-shore profiles; $\Delta x$ is long -shore discretization step; $Q_{\text {sou }}(x)$ is the volume of source/sink term.

\section{Trang 46}


The general long-shore transportation is mapped out in Fig. 2 and Fig. 3 in which $Q_{i}$ denotes the transport rate between $x_{i}$ and $x_{i+1}$, while $d Q_{i}$ denotes the change in the transport rate with respect to change in coastline orientation (for values of $\Theta$ close to the local orientation $\left.\theta_{0}\right)$.

$d Q(x)=\frac{d Q}{d \theta}\left(x, \theta_{0}\right)$

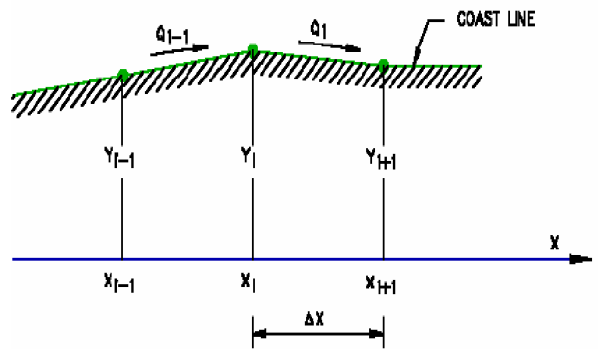

Figure 2. Long-shore discretization

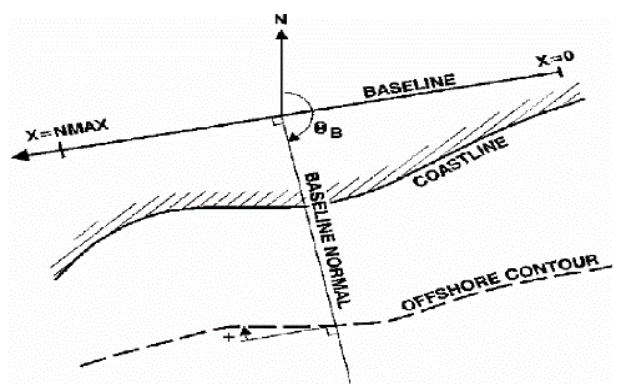

Figure 3. Definition of base line orientation

To assess the potential shoreline change due to the impact of sea level rise, scenarios of sea level rise of 10 $\mathrm{cm}, 15 \mathrm{~cm}, 20 \mathrm{~cm}$ and $25 \mathrm{~cm}$ in respective year of 2020 , 2030, 2040 and 2050 have been established. Shoreline extracted from Landsat image is used to verify simulated results.

\section{Detected shoreline changes}

\section{Before 1995}

Satellite data analyzing shows that, the beach eroded seriously in average of $11.5 \mathrm{~m} /$ year. In period of 1973-1989, erosion occurred with a catastrophic rate (25-30 m/year) at the Can Thanh (section A-B) and 15 $\mathrm{m} /$ year at section C-D. While, the erosion rate at Dong Hoa is around 15 m/year (E-F section). Fig. 4 presents the shoreline change analyzed results at Dong Hoa and Can Thanh cape in this period.
Fig. 5 assesses the shoreline change at Can Gio beach from 1989 to 1995, results show that, the Ly Nhon (green highlighted) and the An Thanh (yellow highlighted) is significantly deposited while erosion occurred at the Dong Hoa (red highlighted). Since 1982, the Can Gio beach was protected by structure; however, the protective ability of these structures had been limited due to its rude technology.

\section{Period of 1995-2004}

By effect of the tropical storm Linda in 1997, the Can Gio sea dike had been damaged. To 1998, the sea dike had been upgraded to "hard structure" by quarry structures and the groin system completed in 2002. Effectiveness structures protected the beach from the erosion. To 2006, the Durian attacked to Can Gio area and damaged the sea dike. Fig. 6 presents the shoreline analysis in this period.

\section{Period of 2004-2013}

Downgrading of the sea dike combined with the tropical storms, beach erosion at Can Gio occurred more frequently. Fig. 7 compares the shoreline change in Dong Hoa and Can Thanh from 2004 to 2013. It is shown that, seasonal surface erosion is predominant in this period, i.e. the beach was eroded in the winter and then it was replenished in the summer.

\section{Conceivable mechanism of the shoreline change}

Erosion at Can Gio beach occurs by multi-impact of wave and high tide. Littoral material composition (fine sand and mud) also contributes to general beach erosion. Fig. 9 presents the simulated current at the Can Gio area. It is shown that, the long-shore currents are dominant to the cross-shore current.

Fig. 10 presents the wave interaction at Can Gio beach. In the summer (Southwest monsoon season) South wave is dominant with maximum wave height is around $0.3 \mathrm{~m}$. in the winter, the Northeast generates the higher wave height, maximum at 0.5 to $0.7 \mathrm{~m}$. Wave height causes erosion whenever the tide is high.

The Can Gio significantly affected by the semidiurnal regime tidal from the estuary, on the rainy season (summer) the average discharge from Soai Rap and Long Tau rivers is around 600 to $1000 \mathrm{~m}^{3} / \mathrm{s}$. This trends to generate the sand bars in front of the estuaries 
and the Can Gio foreshore. These sand bars take effect as the "natural breakwaters" in front of the shore and relocate the breakwater line $(\mathrm{H}=1.28 \mathrm{~h})$ to offshore. The beach therefore is accelerated in this period. Fig. 11a simulates the bed thickness change on the summer. On the dry season (winter), low discharge from rivers (less than 100 to $300 \mathrm{~m}^{3} / \mathrm{s}$ ) leading to decrease the sediment source to the shoreline. By affected of Northeast monsoon season, wave height in this season is around 0.5 to $1.25 \mathrm{~m}$, the breakwater line is close to shoreline and potentially damage the shoreline whenever the tide is high. Fig. 11b simulates the bed thickness change on the winter.

Besides, human activities (aquaculture, coastal structure, tourist, hydroelectric power...) also contribute to the balance of the coastal morphology. Fig. 12 presents the conceivable mechanism of the beach erosion due to aquaculture. It is shown that, by cutting of the mangrove forest for aquaculture, the aggressively easily occurs.

\section{Prediction of shoreline change under the sea level rise}

Simulated shoreline change due to sea level rise is established with increment of the mean sea level in accordance with climate change for Vietnam, published on 2012 by Ministry Of Natural Resource and Environment (MONRE). Fig. 13 presents the simulated results for shoreline change. It is shown that, by impact of sea level rise, the Dong Hoa and Can Thanh cape eroded seriously.

\section{CONCLUSION}

Coastal process in Can Gio area varies seriously, rate of erosion various depends on state of the related activities. It is concluded that, erosion at the Can Gio beach is the surface erosion impacted by the wave interaction and long-shore current. Moreover, human activities (aquaculture, coastal structure, hydroelectric power...) are also main contributors to the balance of the erosion/deposition at the area. In the tendency of sea level rise due to climate change, potential erosion, inundation... in the Can Gio coastal zone is very likely. Therefore, consideration of the change on urbanization, tourist development in the lowland area is necessary. This may both mitigate the negative impacts from the nature phenomena and ensure a sustainable development for the area.

Acknowledgement: The authors would like to thank AUN/SEED-Net and JICA have supported the fund for doing this research. We also thank JICA's staffs and HCMUT's staffs took the time and supported the documents to get the fund.

\section{Trang 48}




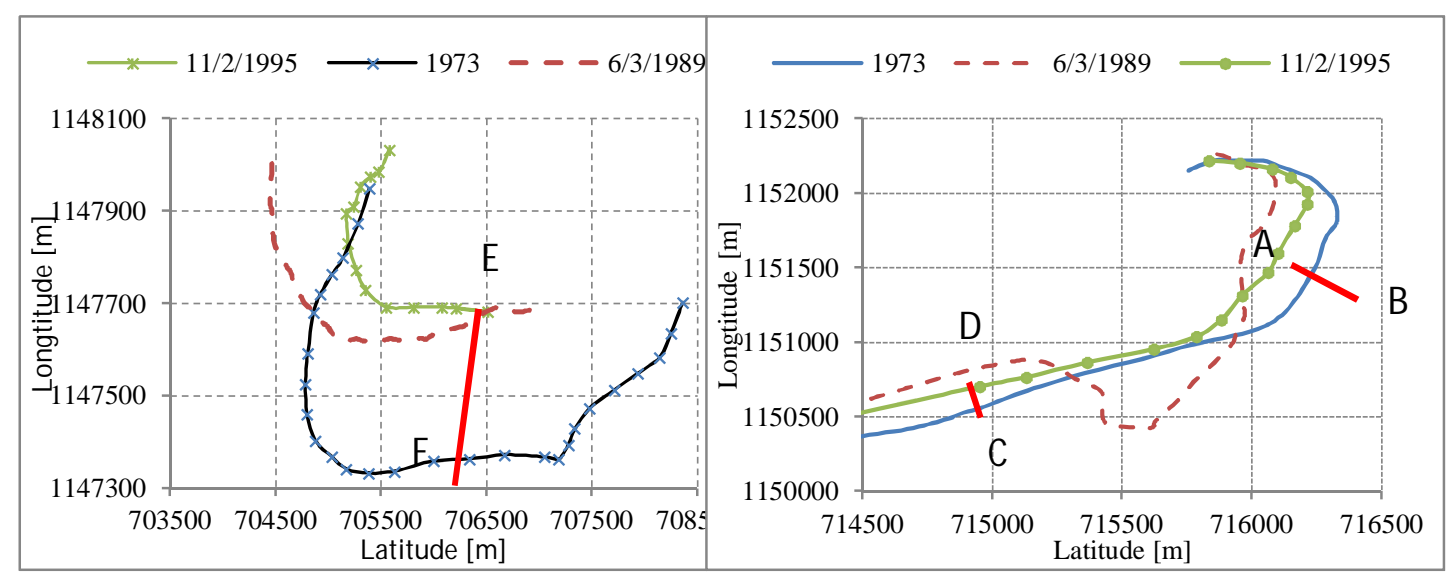

Figure 4. Analyzed shoreline change from 1973 to 1995
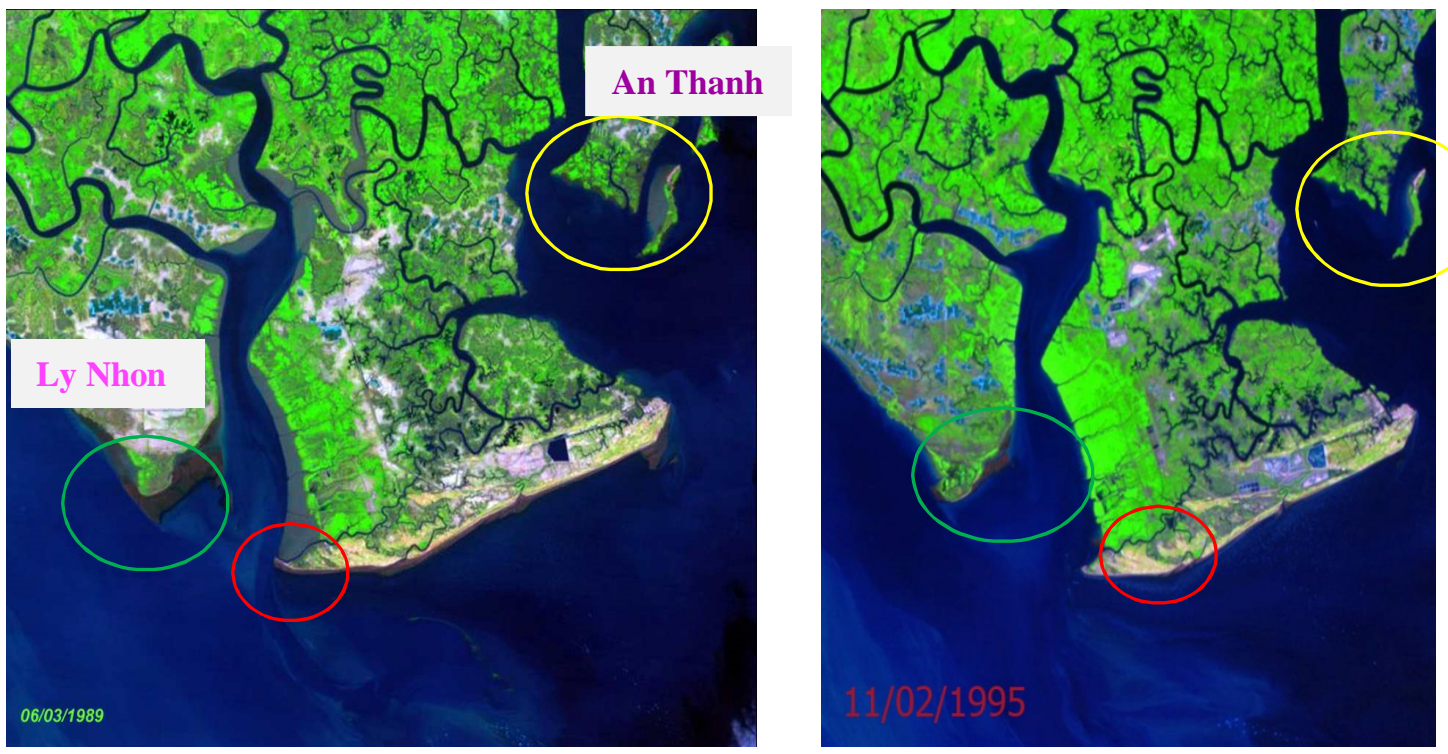

Figure 5. Shoreline change from 1989 to 1995 (Source: USGS)

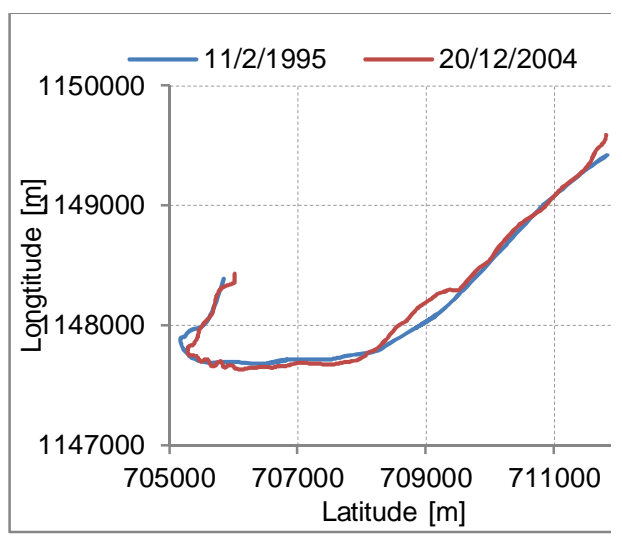

(a) Dong Hoa cape

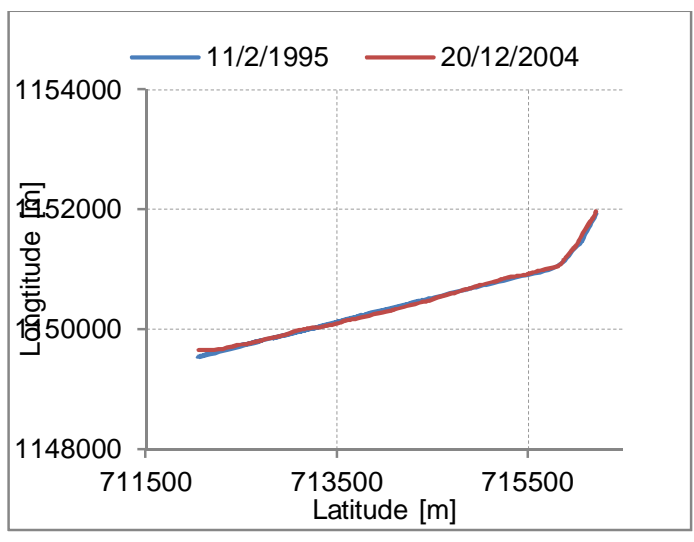

(b) Can Thanh cape

Figure 6. Shoreline change from 1995 to 2004 


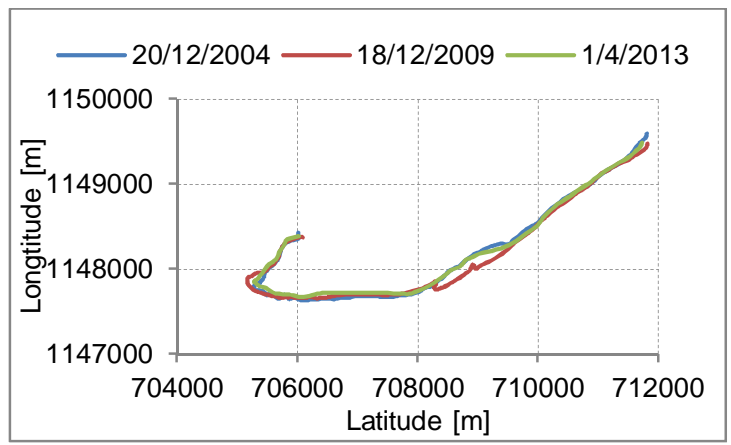

(a) Dong Hoa cape

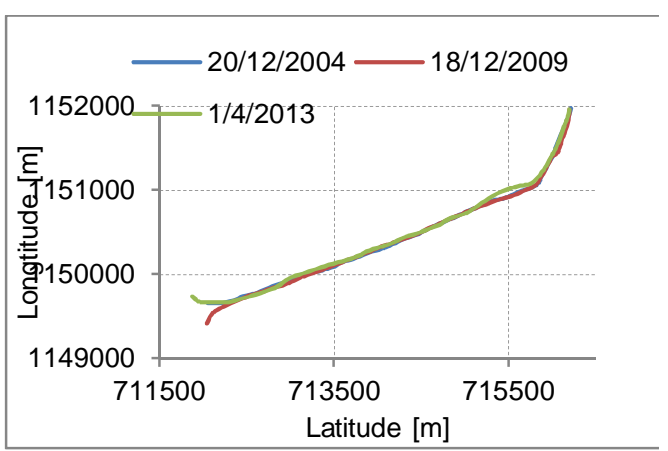

(b) Can Thanh cape

Figure 7. Detected shoreline change from 2004 to 2013
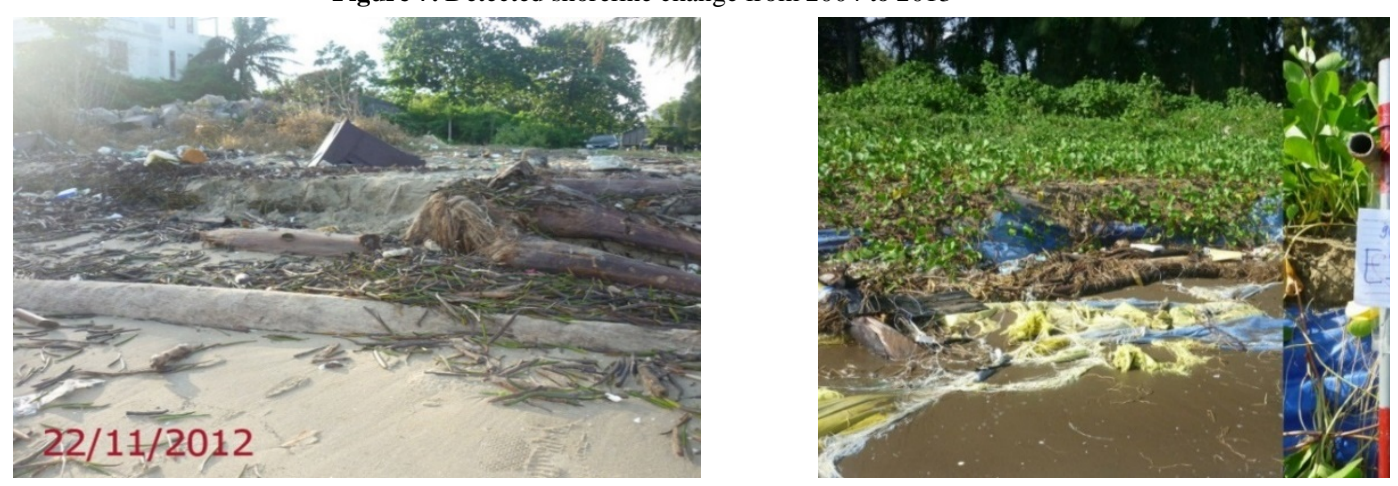

Figure 8. Coastal erosion at Can Gio beach
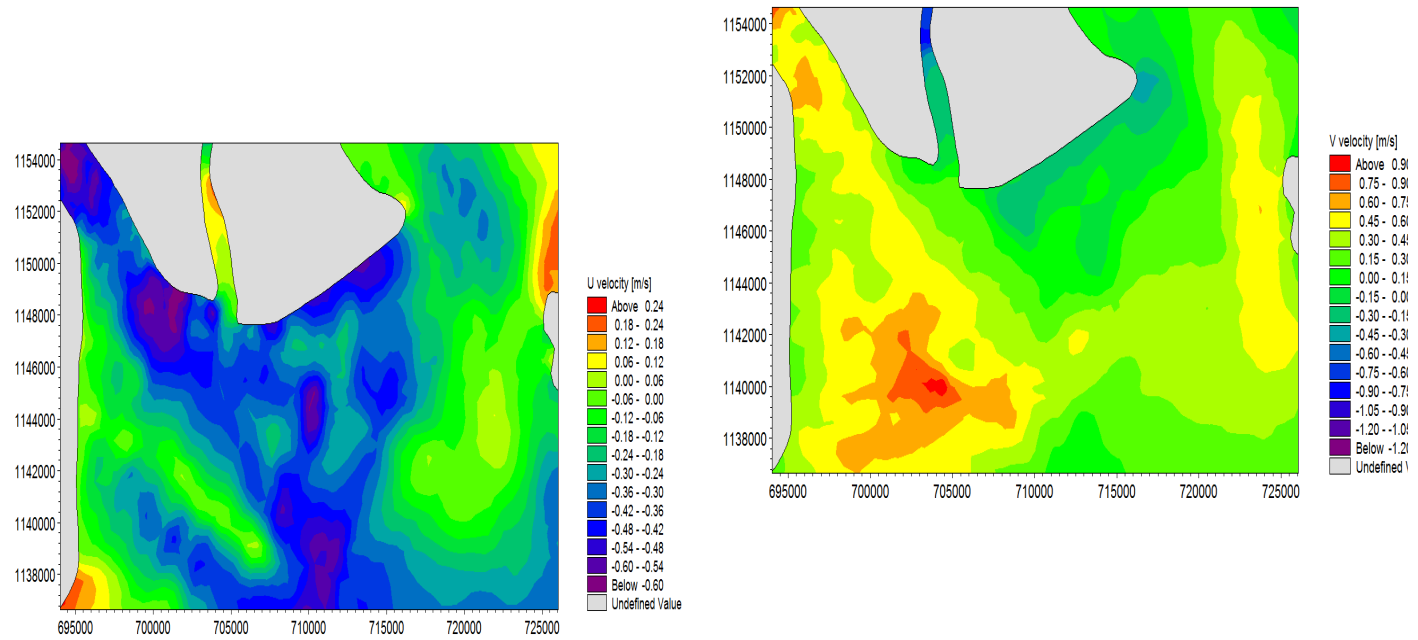

Figure 9. Distribution of long-shore and cross-shore current

\section{Trang 50}




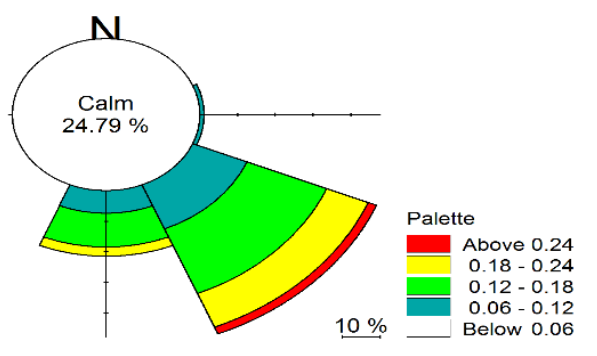

(a) Southwest monsoon season

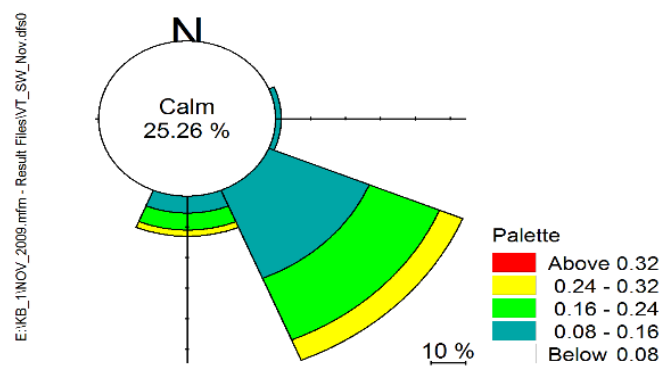

(b) Northeast monsoon season

Figure 10. Wave distribution at Can Gio

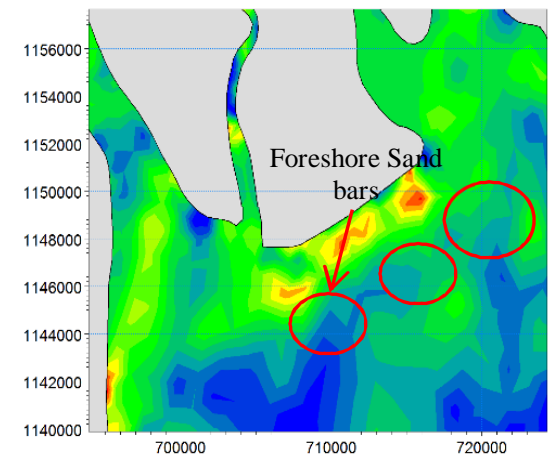

(a) In the summer

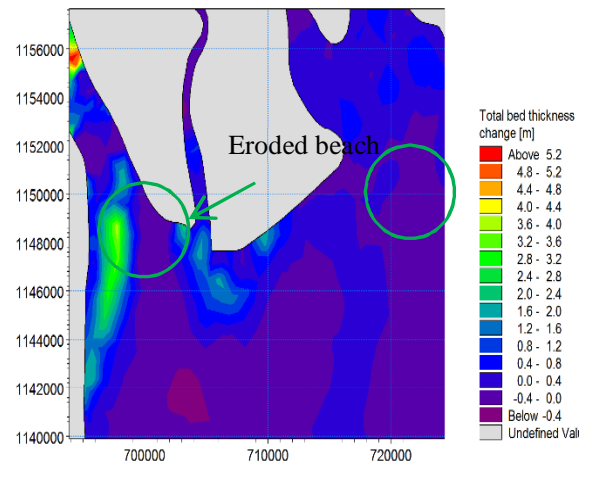

(b) In the winter

Figure 11. Comparison of the bed thickness change
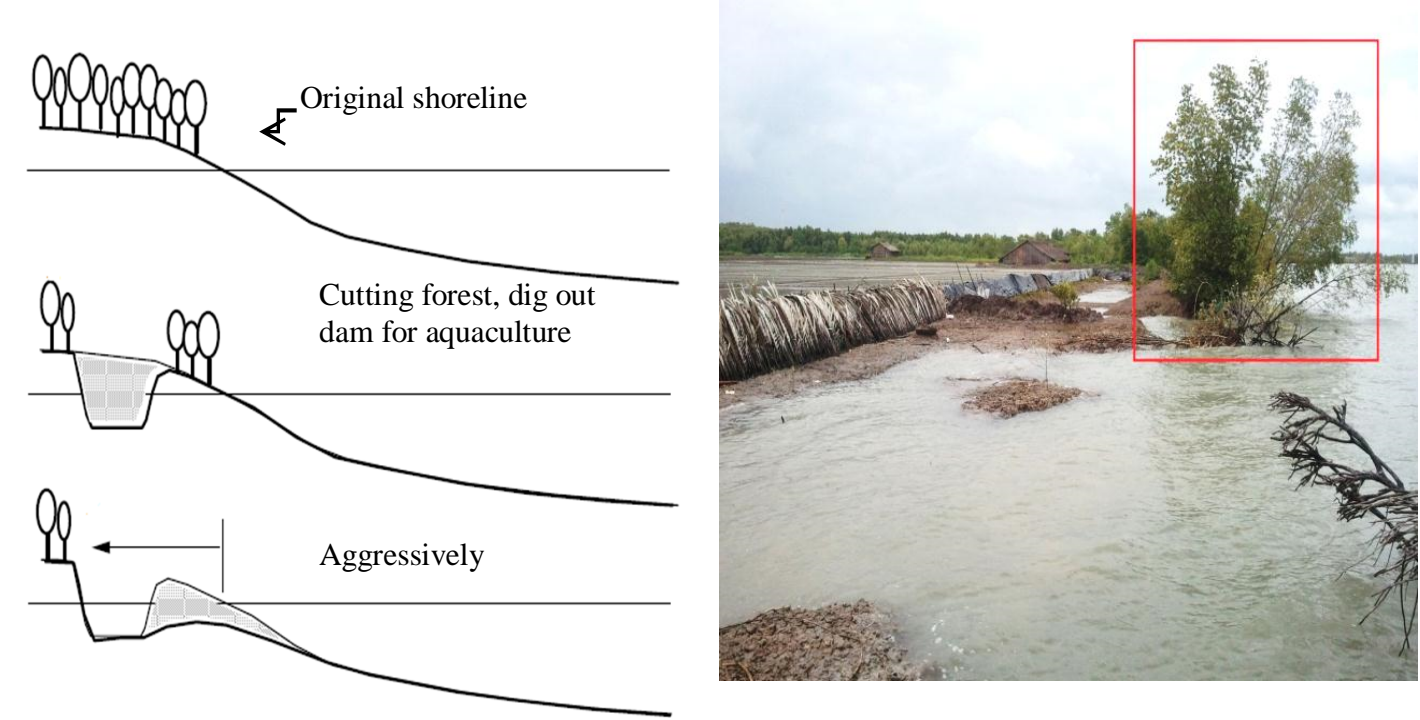

Figure 12. Conceivable erosion mechanism due to aquaculture 


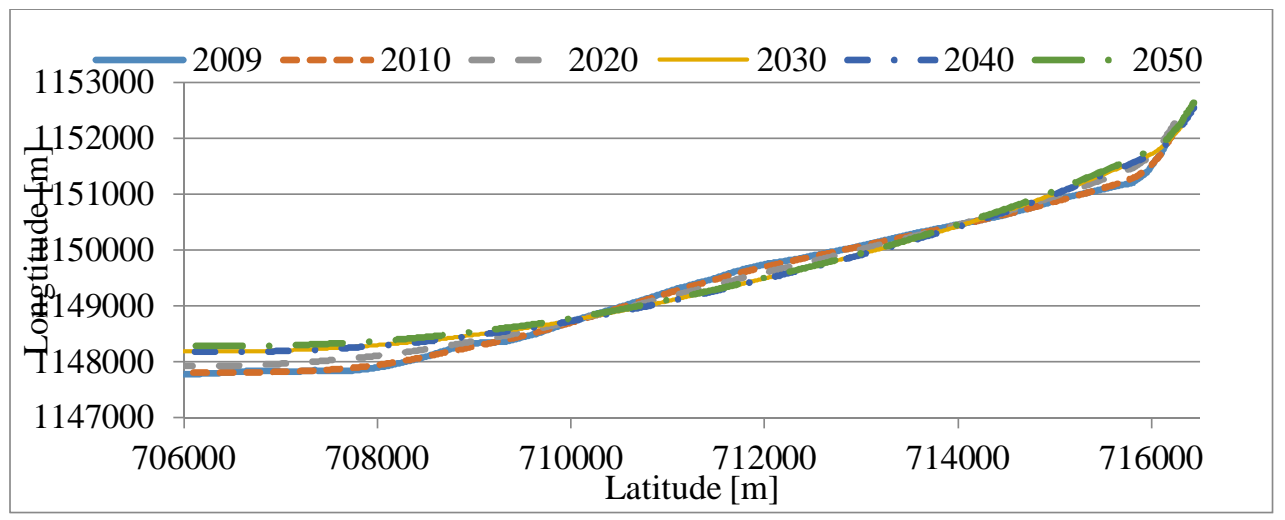

Figure 13. Predicted shoreline impacted by sea level rise

\section{Quan trắc và dự báo sự thay đổi đường bờ tại Cần Giờ trong điều kiện nước biển dâng}

- Bùi Trọng Vinh

- Huỳnh Trung Tín

- Lý Minh Hoàng

- Lê Nguyễn Đoan Trinh

- Lê Thanh Phong

- Trần Lê Thế Diễn

Trường Đại học Bách khoa, ĐHQG-HCM

\section{TÓM TÁT:}

Nằm tại vị trí cửa ngõ giao thông quan trọng trong nước và quốc tế (tuyến Lòng Tàu, tuyến Soài Rạp), khu vực Cần Giờ chịu ảnh hưởng rất lớn từ hoạt đông giao thông thủy. Sự dịch chuyển của các dải cát theo mùa cũng làm thay đổi mạnh mẽ thuỷ động lực ở khu vực cửa sông. Do có vị trí địa lý cực kì quan trọng, nhóm tác giả đã quan tâm đến các yếu tố địa mạo khu vực bờ biển dưới tác động của chế độ thuỷ động lụcc. Trong bài báo này nhóm tác giả đã sử dụng một số nghiên cứu từ trước, kết hợp với sử dụng ảnh vệ tinh nhằm xác định sự thay đổi đường bờ từ năm 1973 đến 2013. Ngoài ra, nhóm tác giả sử dụng mô hình số nhằm dụ̣ đoán sụ̣ thay đổi đường bờ trong điều kiện mực nước biển dâng. Kết quả là, Cần Giờ có mức xói lở cao nhất tại khu vực Đông Hoà, lên đến 7-10m/năm, cao nhất lên đến $15 \mathrm{~m} / \mathrm{năm}$. Nghiên cứu cũng chỉ ra rằng xói lở tại khu vực Cần Giờ chịu ảnh hưởng của nhiều tác động: tác nhân con người (nuôi tôm, lấn biển). Thêm vào đó các tác nhân tự nhiên nWhư yếu tố sóng, dòng dọc bờ', vận chuyển trầm tích cũng làm ảnh hưởng đến xói lở bờ biển. Trong mô hình dụr báo cho thấy rằng với kịch bản nước biển dâng, hai điểm Đông Hoà và Cần Thạnh sẽ xói lở nghiêm trọng, nhưng tại bãi biển 30-4 thì lại được bồi tụ.

Từ khóa: Cần Giờ, xói lở bờ biển, mô hình số, GIS, nước biển dâng.

\section{Trang 52}




\section{TÀI LIỆU THAM KHẢO}

[1]. Bui T.V., Deguchi I., Arita M. Erosion Mechanisms of Cohesive Bed and Bank Materials (2009). Proceedings of the Annual International Offshore and Polar Engineering Conference \& Exhibition (ISOPE). Osaka, Japan, Vol. III, pp. 1305-1312.

[2]. Hai Q. Ha, Tuyen N. Nguyen (2010). Coastal erosion in Can Gio under the global sea level rise. Journal of Science and Technology, P. 14, S.4M, 2011.

[3]. Vinh T. Bui, Deguchi I. (2012). Erosion mechanism of cohesive heb and band material at the SoaiRap river (Ho Chi Minh city). Journal of Sciences on Earth, Vol. 34m, 2012.
[4]. Deguchi I., Sawaragi T. Effects of structure on deposition of discharged sediment around river mouth. Proc. of 21st International Conference on Coastal Engineering, Vol.2, pp. 1573-1587, 1988.

[5]. "Environmental Impact Assessment Report - The Can Gio Sand Exploitation Project", Report of Modimo Mining, Geology and Environment Joint Stock Company, 2012.

[6]. Wiebe P. de Boer et. Al (2011). Impact of megascale sand extraction on tidal dynamics in semienclosed basins. An idealized model study with application to the Southern North Sea. Journal of Coastal Engineer 58, pp. 678-689, 2011.

[7]. DHI, 2007. MIKE 21/3 Coupled model FM stepby-step training guidelines 